\title{
Repetitive DNA sequences in Crocus vernus Hill (Iridaceae): The genomic organization and distribution of dispersed elements in the genus Crocus and its allies
}

\author{
S. Frello and J.S. Heslop-Harrison
}

\begin{abstract}
Eight clones of repetitive DNA were isolated from Crocus vernus Hill. The genomic organization of the clones was analyzed by in situ hybridization to C. vernus and Southern hybridization to a range of Crocus and other species. Seven clones were used for in situ hybridization. Sequence analysis showed that all eight clones were nonhomologous, and thus represented eight different sequence-families. In situ hybridization showed that six were dispersed in high copy numbers on all chromosomes of the $C$. vernus genome, whereas one was localized proximal to the secondary constriction, at the NOR (nucleolar organizer region) and was not further analyzed, as it was considered part of the 18S-25S rDNA repeat. Except for short palindromes, none of the sequences showed notable internal structures. Clone pCvKB4 showed homology to the reverse transcriptase gene of Ty1-copia-like retrotransposons; the others showed no homology to known sequences. When used as probes for Southern hybridization, four showed a ladder of 3-4 bands superimposed by irregular patterns, indicating organization in short tandem arrays. Each clone had a unique distribution among Crocus species (12-16 species analyzed with each clone) and six species of Iridaceae, Liliaceae, and Amaryllidaceae; all seven investigated sequences were Iridaceae specific and four were Crocus specific. The species distribution of these seven clones showed notable discrepancies with the taxonomic subdivision of the genus at the subgenus, section, and series levels. The results suggest that the phylogeny and taxonomic structure of the genus Crocus might need reconsideration. The analysis of repetitive DNA as a major and rapidly evolving part of the genome could contribute to the study of species relationships and evolution.
\end{abstract}

Key words: phylogeny, evolution, in situ hybridization, sequence analysis, dispersed elements.

Résumé : Huit clones d'ADN répétitif ont été isolés du Crocus vernus Hill. L'organisation génomique de ces clones a été analysée par hybridation in situ chez le C. vernus et par hybridation Southern chez une gamme d'espèces du genre Crocus et d'autres encore. Sept clones ont été employés en hybridation in situ. Les analyses de séquences ont montré que les huit clones étaient nonhomologues et représentaient ainsi des familles de séquences distinctes. L'hybridation in situ a montré que six des séquences étaient dispersées en grand nombre sur tous les chromosomes du C. vernus tandis qu'une séquence était située du côté proximal de la constriction secondaire, à l'organisateur nucléolaire (NOR), et n'a donc pas été analysé davantage étant considérée comme faisant partie de la répétition $18 \mathrm{~S}-25 \mathrm{~S}$. À l'exception de courts palindromes, aucune des séquences ne montrait de structure interne notable. Le clone pCvKB4 montrait de l'homologie au gène codant pour la transcriptase inverse des rétrotransposons de type Ty1-copia. Les autres clones ne montraient de l'homologie à aucune séquence connue. Lorsque ces clones ont été employés comme sondes lors d'hybridations Southern, quatre clones ont produit des échelles de trois à quatre bandes superposées de motifs irréguliers, cela étant indicatif d'une organisation en courtes suites de répétitions en tandem. Chaque clone avait une distribution unique parmi les espèces de Crocus (12 à 16 espèces examinées selon le clone) et parmi six espèces d'iridacées, de liliacées et d'amaryllidacées. Les sept clones étaient spécifiques aux iridacées et quatre d'entre eux étaient spécifiques au genre Crocus. La distribution des ces clones au sein des espèces a montré des différences par rapport aux subdivisions taxonomiques du genre Crocus aux niveaux du sous-genre, de la section et de la série. Les résultats suggèrent que la phylogénie et la structure taxonomique du genre Crocus pourraient nécessiter certaines remises en question. L'étude de l'ADN répétitif, en tant que composante du génome à la fois importante et en rapide évolution, pourrait contribuer à l'étude des relations interspécifiques et de l'évolution.

Corresponding Editor: J.H. de Jong.

Received December 22, 1999. Accepted May 23, 2000. Published on the NRC Research Press web site on September $22,2000$.

S. Frello. Section of Botany, The Royal Agricultural and Veterinary University, Rolighedsvej 21 1958 Frb.C, Copenhagen, Denmark. J.S. Heslop-Harrison. ${ }^{1}$ Karyobiology Group, John Innes Centre, Norwich NR4 7UH, U.K.

${ }^{1}$ Author to whom all correspondence should be addressed at Department of Biology, University of Leicester, Leicester LE1 7RH, U.K. (e-mail: PHH@genome.waitrose.com). 
Mots clés : phylogénie, évolution, hybridation in situ, analyse de séquence, éléments dispersés.

[Traduit par la Rédaction]

\section{Introduction}

Crocus vernus Hill, with the two subspecies $C$. vernus subsp. vernus and $C$. vernus subsp. albiflorus, is a welldefined taxon distributed throughout most mountainous regions of Southern Europe. The species is morphologically variable and presents a range of karyotypes at the diploid and polyploid levels; all accessions have large genomes and very large chromosomes. Crocus taxonomy has until now been based primarily on morphology, taking chromosome numbers into consideration (Mathew 1982). Little is known about the genetics and genome structure of the genus and, based on data from other species groups, such information is likely to help understand the evolutionary processes, relationships, and diversity within the genus.

The major fraction of most plant genomes is made up of repetitive DNA sequences; short sequence motifs repeated thousands of times, which may be present as tandem arrays at a discrete number of genomic locations, or dispersed over much of the genome (Flavell 1986; Kubis et al. 1998). The genomic function of most repetitive sequences is largely unknown, but some are genes (e.g., the rDNA), and others are involved in chromosome segregation at the centromere, or stabilization of chromosome ends (Vershinin et al. 1995). It has been suggested that repetitive sequence accumulation might be greater in slow-growing, long-lived species than in species with faster development (Charlesworth et al. 1994). Although some repetitive sequences are highly conserved (the rRNA genes, for example), many repetitive DNA motifs are restricted in their distribution to single species, species groups, or genera.

A major class of dispersed repetitive elements, the retrotransposons, amplify through an RNA intermediate, are abundant in all living organisms (Flavell et al. 1992), and are well studied in plants (e.g., Kumar et al. 1997; Flavell et al. 1997). Retroelements alone may represent $50 \%$ of the total DNA in a plant genome (Pearce et al. 1996), although other abundant dispersed repeats with no known homology to retroelements have also been found in species such as barley (Busch and Hermann 1997) and sugar beet (Kubis et al. 1997). Avramova et al. (1995) suggest that some dispersed sequences function as matrix attachment regions (MARs) and influence gene transcription. The abundance of dispersed repeats makes investigation of their evolution, occurrence, organization, and structure important to our understanding of the plant genome. Because of the diversity and rapid evolution of repetitive sequences, they are potentially valuable markers in phylogenetic and biodiversity studies (de Bustos et al. 1996; Svitashev et al. 1994) and for the investigation of hybrids (Itoh et al. 1990).

As part of a project in Crocus cytology, phylogeny, and evolution (Ørgaard et al. 1995) we present here the investigation of multiple clones of repetitive DNA from $C$. vernus. The clones were sequenced and investigated with respect to genomic organization and physical distribution on the C. vernus genome, and their presence in various Crocus species as well as more distantly related genera.

\section{Materials and methods}

\section{Plant material}

Table 1 provides the details of the origins of the plant accessions used in this study. All accessions are grown at the institution indicated by the accession number.

\section{DNA extraction and cloning}

DNA was extracted from flowers (preferably just before opening) by standard methods (Sambrook et al. 1989). A recombinant DNA library was made from a Sau3AI partial digest of genomic DNA from C. vernus in the BamHI site of pUC18. Highly repetitive cloned sequences were identified by probing a dot-blot of the clones with labelled genomic DNA. Selected clones were named (p for plasmid, $\mathrm{Cv}$ to designate the species, and $\mathrm{KB}$ for the karyobiology laboratory), labelled, and hybridized to Southern transfers of Sau3AI digests of DNA from C. vernus, and clones showing strong hybridization signals were used in further work. Selected clones were sequenced commercially and analyzed by in situ and Southern hybridization.

\section{In situ hybridization}

Preparation of young roots from corms and in situ hybridization followed the methods described by Schwarzacher and HeslopHarrison (2000). Fresh root tips were incubated $24 \mathrm{~h}$ in ice water, fixed in alcohol : acetic acid (3:1) and digested for 40-50 min in a mixture of pectinase and cellulase, sometimes with the addition of $0.5 \%$ pectolyase. In situ hybridization implemented $40 \mathrm{ng}$ of probe DNA labelled with biotin or digoxigenin in $40 \mu \mathrm{L}$ hybridization buffer per slide. Preparations with denatured probe were denatured at $70^{\circ} \mathrm{C}$ for $8 \mathrm{~min}$ and allowed to hybridize overnight at $37^{\circ} \mathrm{C}$. The most stringent wash following hybridization was either at $42^{\circ} \mathrm{C}$ in $0.1 \times \mathrm{SSC}(20 \times \mathrm{SSC}$ is $3 \mathrm{M} \mathrm{NaCl}, 0.3 \mathrm{M}$ sodium citrate) and $20 \%$ formamide, allowing target sequences of more than $85 \%$ homology to remain hybridized (low stringency) or at $42^{\circ} \mathrm{C}$ in $0.032 \times \mathrm{SSC}$ and $25 \%$ formamide, allowing target sequences of more than $95 \%$ homology to remain hybridized (high stringency).

Streptavidin-Cy3 and antidigoxigenin-FITC (fluorescein isothiocyanate) were used to detect probe hybridization sites, and preparations were counterstained with DAPI (4',6-diamidino-2phenylindole). Micrographs were made on 400 ASA Fuji Superia or SuperHG colour film with an epifluorescence microscope, digitized to Kodak РнотосD and processed with Adobe Рнотоsнор, using only functions affecting the whole image equally.

\section{Molecular analysis of DNA}

Sequence homologies with other sequences were investigated by searching the GenBank and EMBL databases (release 103). Five micrograms DNA from the Iridaceae species and $15 \mu \mathrm{g}$ DNA from each of the other species were digested with Sau3AI and sizeseparated on a $1 \%$ agarose gel. DNA was visualized with ethidium bromide and photographed to confirm equal loading before Southern blotting on Hybond $\mathrm{N}^{+}$membranes. Probe labelling and hybridization was performed with the ECL Random Prime method (Amersham) according to the manufacturer's instructions. X-ray film was used to visualize the signal. Each blot was used only once.

\section{Results}

\section{In situ hybridization}

When used for in situ hybridization, clones pCvKB3, 
Table 1. Accession numbers and origin of plants used in this study.

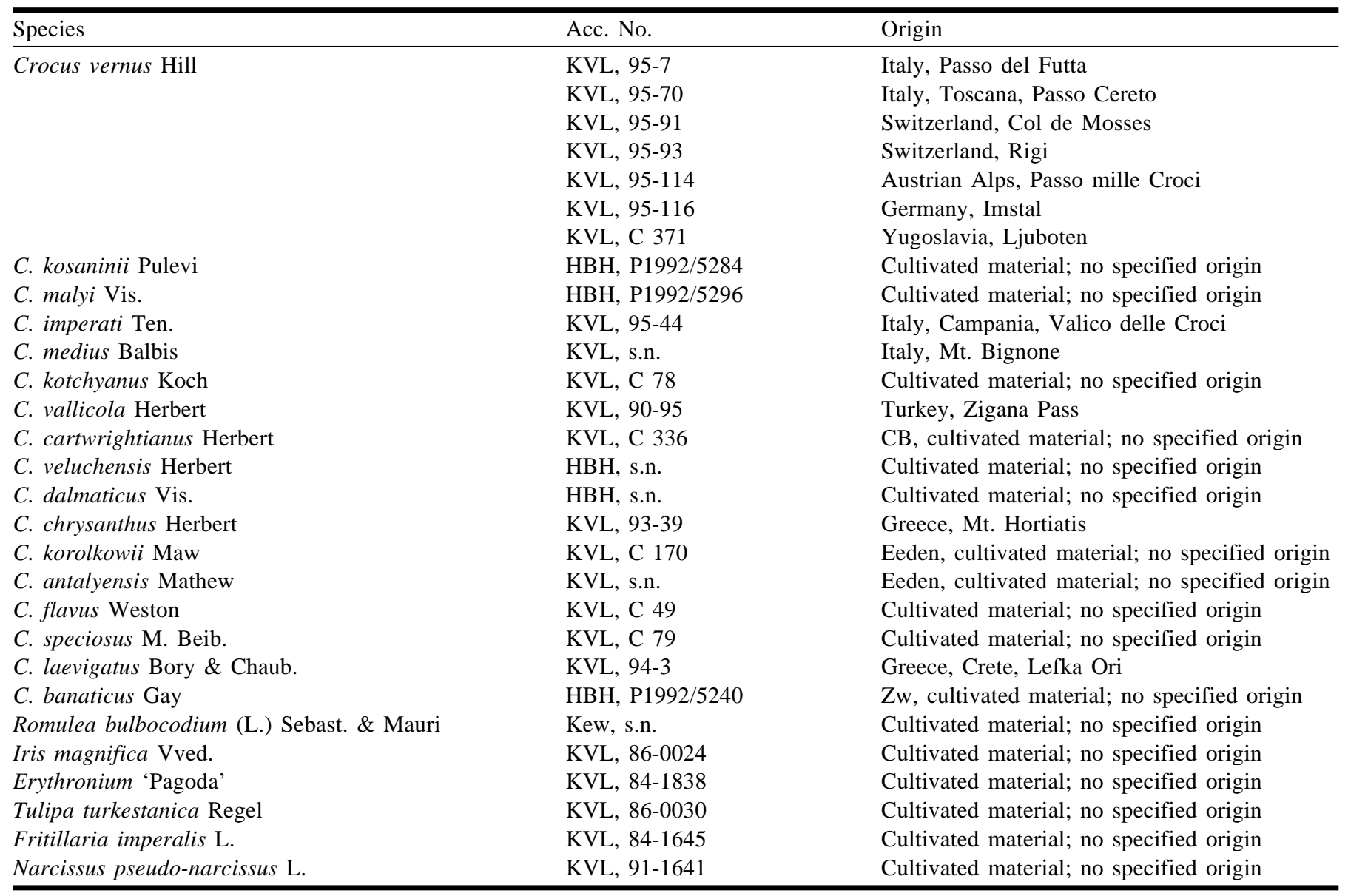

Note: Different $C$. vernus accessions have been used both for Southern and in situ experiments with the different clones. Abbreviations: s.n., Without number; HBH, The Botanical Garden of the University of Copenhagen, Denmark; KVL, Royal Veterinary and Agricultural University, Copenhagen; Eeden, provided by P.W. van Eeden, The Netherlands; CB, Provided by Cambridge Bulbs, U.K.; Zw, provided by Zwanenburg Nurseries, Haarlem, The Netherlands.

pCvKB4, pCvKB5, pCvKB6, pCvKB9, and pCvKB10 showed a rather similar dispersed organization over the lengths of the chromosomes, with areas of slightly weaker or stronger hybridization (Figs. 1-3); these minor differences, seen on multiple metaphases, different accessions, and in both $C$. vernus subspecies, are described below. pCvKB2 hybridized to part of the 18S-25S rRNA locus, labelling much of the satellite and often part of the chromosome arm proximal to the satellite (Fig. 1c). pCvKB5 was used for in situ hybridization at two different stringencies: at the lower stringency $(80-85 \%$, Fig. $1 b)$, it showed a dispersed pattern along the whole length of all chromosomes with small gaps at the centromeres and larger gaps (arrows) at the sites of the rDNA (pCvKB2, Fig. 1b,1c) whereas a slightly less uniform signal was obtained at the higher stringency $(95 \%$, not shown). pCvKB3 showed strong hybridization to intercalary regions with less signal in telomeric and centromeric regions (results not shown). pCvKB4 (not shown) showed a dispersed distribution with gaps at the centromeres, stronger hybridization signals on both sides of the centromere of most chromosomes, and gaps at the rDNA loci. pCvKB6 (Fig. $3 b$ ) showed a more uniform hybridization pattern than pCvKB5, whereas pCvKB9 (Fig. 2b) hybridized slightly more strongly to some intercalary regions, with weaker hybridization at centromeres and some distal regions.
pCvKB10 (Fig. 2a) was less uniform than other sequences, with some chromosomal regions and satellites showing stronger hybridization.

\section{Sequence analysis}

Table 2 summarizes information about eight nonhomologous sequences reported here, including their database accession numbers. pCvKB1 had an AT content of $45 \%$ (compared with an average of $57 \pm 2.5 \%$ SD for the other sequences), and an unusual internal structure of $32 \mathrm{bp}$, including overlapping 8-bp (three) and 6-bp (two) palindromic sequences (Fig. 4). Only pCvKB4 showed homology to existing sequences: it included a fragment of a reverse transcriptase gene from a copia-like retroelement, revealed by $>60 \%$ homology at the nucleotide level to genes isolated from Platanus occidentalis, Hordeum vulgare, and Helianthus annuиm. No notable features were detected in the other repeats.

\section{Southern hybridization}

Table 3 summarizes the strength of hybridization of the seven clones to genomic DNA digests from Crocus (Table $3 a$ ) and other genera (Table $3 b$ ). No clones hybridized to species from the Liliaceae and Amaryllidaceae; only pCvKB4, pCvKB5, and pCvKB6 were present in the 
Fig. 1. In situ hybridization (red and green signal) of repetitive DNA sequences from $C$. vernus to metaphase chromosomes from $C$. vernus subsp. vernus $\times 1200$. (a) Staining of chromosomes with DAPI. $(b, c)$ Dispersed hybridization of pCvKB5 (green, $b$ ) showing exclusion from the rDNA regions (arrows; pCvKB2, red, $c$ ). Fig. 2. In situ hybridization (red and green signal) of repetitive DNA sequences from $C$. vernus to metaphase chromosomes from $C$. vernus subsp. albiflorus $\times 1200$. pCvKB10 (green, $a$ ) shows weaker hybridization than pCvKB9 (red, $b$ ), but relatively equal hybridization to most chromosome segments. pCvKB9 is dispersed but reduced in broad centromeric regions and some whole chromosome arms. Fig. 3. In situ hybridization (red and green signal) of repetitive DNA sequences from $C$. vernus to metaphase chromosomes from $C$. vernus subsp. vernus $\times \mathrm{S} 1200$. Both $\mathrm{pCvKB5}$ (green, $a$ ) and pCvKB6 $($ red, $b$ ) show dispersed but unequal hybridization to most chromosome arms. ' $\mathrm{x}$ ' indicates stain precipitate.
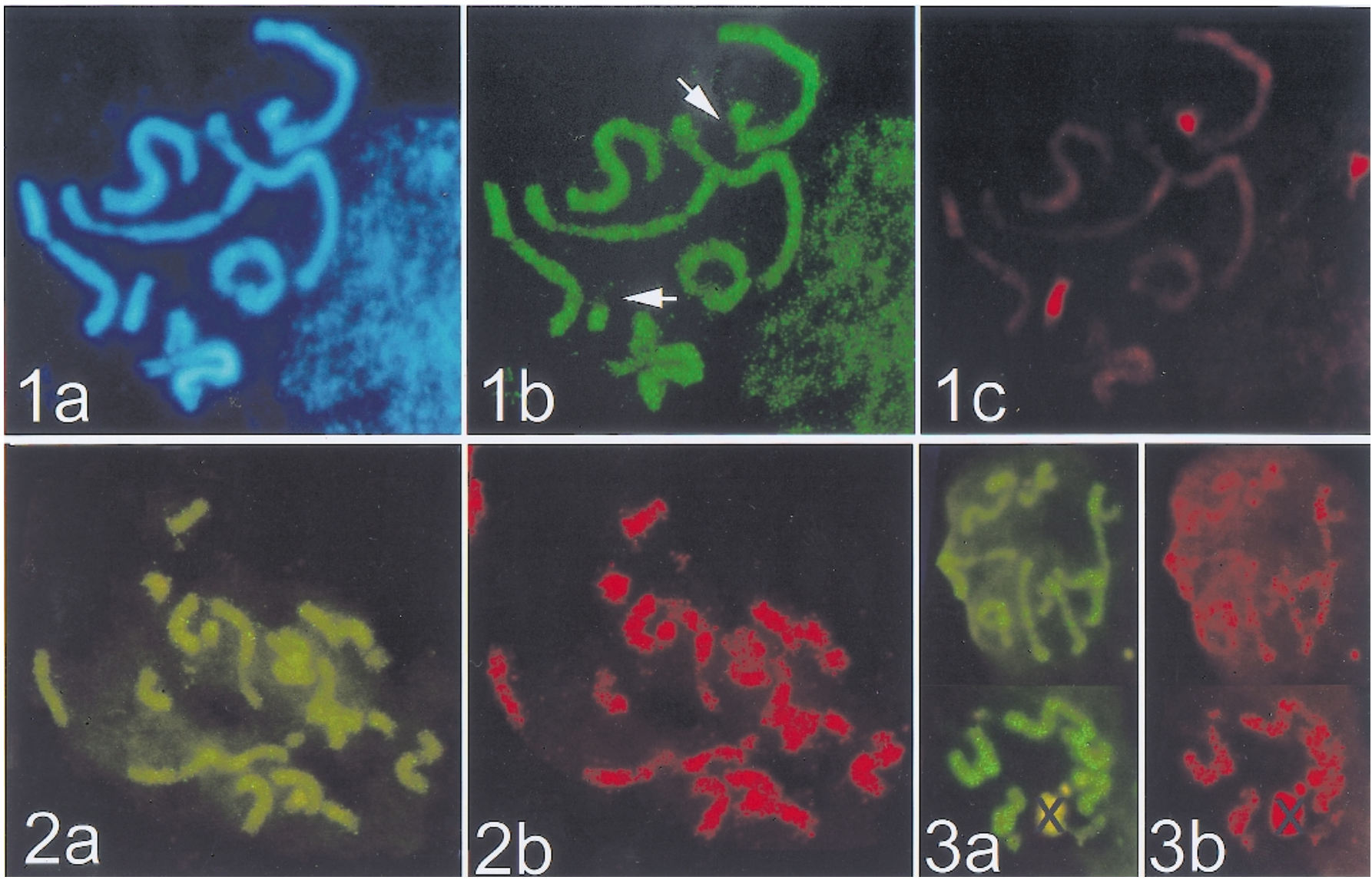

Iridaceae genera Romulea, and only pCvKB5 and pCvKB6 in Iris, the others being specific to Crocus. All clones showed different genomic arrangements by Southern hybridization to genomic DNA digests with Sau3AI (shown for pCvKB4 and 5 in Figs. 5 and 6). The copia-like sequence pCvKB4 hybridized with variable strength to all Crocus species except $C$. korolcowii. It revealed multiple restriction fragments shared by a number of species at $1000 \mathrm{bp}$ and below. High-molecular-weight bands had an underlying hybridization smear (Fig. 5). Southern hybridization of pCvKB5 (971 bp, Fig. 6) revealed more than 15 abundant Sau3AI restriction fragments in $C$. vernus (between 250 and $2500 \mathrm{bp}$ ), and an exceptional species distribution pattern, being absent in half the Crocus species tested but present in Romulea and Iris. The sequence included Sau3AI sites, so some fragments probably represent internal domains. Some bands were parts of a ladder indicating that the sequence occurs in short tandem arrays, although in situ hybridization showed pCvKB5 to be dispersed over the chromosomes (Fig. 1b).

pCvKB1 gave two weak bands, shared by most species where the clone is detected. C. vernus had additional bands.
pCvKB3 produced multiple bands, some of which corresponded to a ladder, with a similar banding pattern in all species varying in intensity. pCvKB6 gave a ladder with conserved low-molecular-weight bands, even in the remote genera Romulea and Iris. The high-molecular-weight bands showed a more complex pattern. pCvKB9 gave a ladder-like pattern in C. vernus with six bands between 200 and $800 \mathrm{bp}$. Two bands at $1300 \mathrm{bp}$ and $1450 \mathrm{bp}$ were present in several species. Except for this, the probe showed multiple polymorphic multiple bands with no detectable pattern, different in all Crocus species where it is detected. pCvKB10 produced a few bands over a smear in most species.

\section{Discussion}

We have investigated the chromosomal and species distribution of cloned nonhomologous repetitive DNA elements from $C$. vernus. The in situ hybridization experiments showed that all but one of the sequence families investigated have an essentially uniform dispersed distribution pattern on all chromosomes of $C$. vernus, but with small differences in the detailed pattern (Figs. 1-3). One sequence, pCvKB2, 


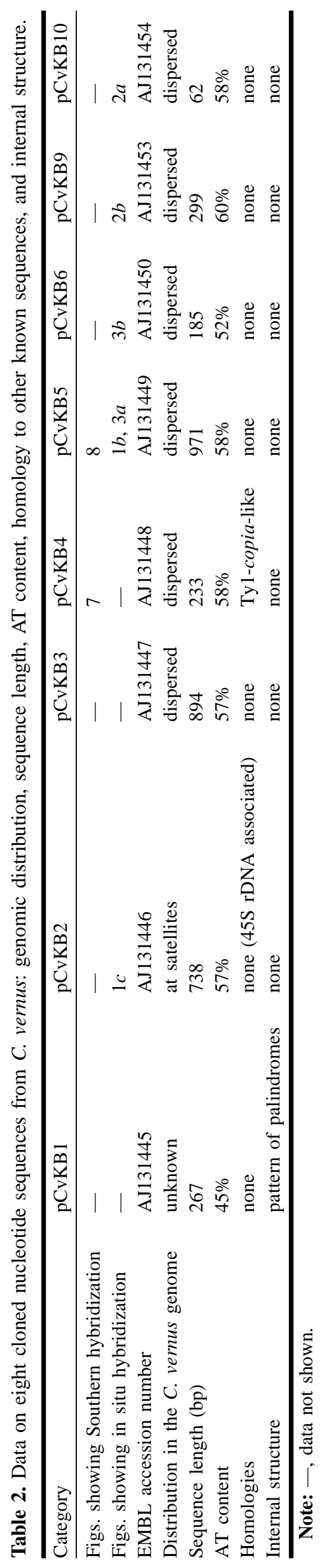

was associated with the 18S-25S rDNA (Fig. 1). Two homologous repetitive sequences from C. vernus, $\mathrm{pCvKB7}$ and pCvKB8, units of a family of tandem repeats with subterminal locations on many chromosomes, are under investigation. Our survey of repetitive elements only found one pair of homologous sequences, and no copies of presumably abundant 5S rDNA, LINE, or gypsy-like retroelements. We therefore suggest that many more families of repetitive DNA can be found in this species. However, the absence of visible restriction fragments in ethidium-bromide-stained agarose gels suggests the absence of very abundant repeats.

The sequence pCvKB4 was homologous to a fragment of a Ty1-copia-like retrotransposon. In many species with large chromosomes, such elements show a dispersed distribution over the chromosomes with gaps at the centromeres and rDNA loci (Brandes et al. 1997). This pattern was also seen in C. vernus. At the level of nucleotide sequence, variation is high enough that copia-like retrotransposons can be used to discriminate species (e.g., gymnosperms, Kamm et al. 1996; Avena, Katsiotis et al. 1996). With one exception (see Table $3 a$ and $3 b$ ), the presence of pCvKB4 divides species of Crocus and Romulea from the more remote species tested.

The mechanism of amplification and dispersion of nonretroelement-related dispersed repetitive elements is not known, since known amplification mechanisms such as unequal crossing-over would not produce the dispersal seen. It is possible that the other sequences analyzed may be diverged or unidentified fragments of retroelements, or cotranscribed with them. When used as probes for Southern hybridization to DNA of other species of Crocus and related genera, each of the seven sequences analyzed here showed a unique distribution pattern among the species (Table 3), although differences between pCvKB3, pCvKB4, and pCvKB6 were small. This indicates that individual clones were not fragments of compound repeats. None of the dispersed sequences was conserved in all Crocus species; the pCvKB8 family also showed a unique species distribution (Frello and Heslop-Harrison 2000). The genomic organization of the pCvKB 8 family revealed by Southern hybridization (Figs. 5, 6, and Results) indicated that some sequences have similar genomic organizations in the different species in which it is present; major restriction fragments were shared in all hybridizing species.

A model of evolution of repetitive elements involves the appearance of a particular sequence at a single point in a phylogenetic lineage, with subsequent amplification and homogenization of the new sequence across the whole genome. Essential refinements of this model take into account the fact that sequences can disappear during evolution, and that most sequences arise as variants of pre-existing sequences. This model fits the Iridaceae phylogeny, with two of the seven sequences being present in the distant genus Iris, and one more in Romulea. It is also supported by extensive data in the tribe Triticeae (e.g., Svitashev et al. 1994), the Chenopodiaceae (Kubis et al. 1997), and other species.

Within the genus Crocus as currently understood (Mathew 1982), such a sequential model of sequence evolution does not fit our data. C. banaticus is taxonomically isolated as the sole member of subgenus Crociris based on unique morphological features. However, the subset of four of the seven repetitive sequences included in its genome does not separate 
Fig. 4. The DNA sequence of pCvKB1. Between bp 119 and 150, the sequence shows a pattern of palindromes. Underlined: 6-bp palindromes. Bold: 8-bp palindromes. Bolding and underlining indicates overlap.

$\begin{array}{lr}\text { GATCTGAGATGTGTCTTCGTTTTGGTTAGACCGATTCTGCGAACGGCCTA } & 50 \\ \text { GCCCCAAGCGGGCCAAGCACGTAGCGATAAGAAAACTTAACACCAGGTTC } & 100 \\ \text { ATTGGTGCTTTGGAGATCCTCTAGAGTCGACCTGCAGGCATGCAAGCTTG } & 150 \\ \text { GCACTGGCCGTCGTTTTACAACGTCGTGACTGGGAAAACCCTGGCGTTAC } & 200 \\ \text { CCAACTTAATCGCCTTGCAGCACATCCCCCTTTCGCCAGCTGGCGTAATA } & 250 \\ \text { GCGAAGAGGCCCGCACCGATC } & \end{array}$

Table 3. Presence of seven clones from C. vernus on genomic DNA from Crocus and allied species, revealed by Southern hybridization (as shown in Figs. 7 and 8). Numbers indicate strength of hybridization signal.

\begin{tabular}{|c|c|c|c|c|c|c|c|c|c|}
\hline Iridaceae: subgenus/section & Series & Species & $\mathrm{pCvKB} 1$ & $\mathrm{pCvKB} 3$ & $\mathrm{pCvKB} 4$ & pCvKB5 & pCvKB6 & pCvKB9 & $\mathrm{pCvKB} 10$ \\
\hline Crocus/crocus & verni & vernus & 2 & 2 & 2 & 2 & 2 & 2 & 2 \\
\hline Crocus/crocus & versicolores & malyi & - & 2 & - & - & - & - & 2 \\
\hline Crocus/crocus & versicolores & imperati & 1 & 1 & 1 & 0 & 2 & 2 & - \\
\hline Crocus/crocus & longiflori & medius & 1 & 1 & 1 & 0 & 2 & 1 & 0 \\
\hline Crocus/crocus & crocus & cartwrightianus & 0 & 2 & - & - & 2 & 1 & 0 \\
\hline Crocus/nudiscapus & reticulati & veluchensis & 0 & 2 & - & - & 1 & 1 & 1 \\
\hline Crocus/nudiscapus & reticulati & dalmaticus & - & 2 & 2 & 1 & - & - & - \\
\hline Crocus/nudiscapus & biflori & chrysanthus & 1 & 2 & 2 & 1 & 2 & 1 & 2 \\
\hline Crocus/nudiscapus & orientalis & korolkowii & 0 & 0 & 0 & 0 & 0 & 1 & 0 \\
\hline Crociris/ - & & banaticus & 0 & 1 & 1 & 1 & 2 & 0 & 0 \\
\hline \multicolumn{10}{|c|}{ (3b.) Results from other genera than Crocus. } \\
\hline Family & Genus & Species & $\mathrm{pCvKB} 1$ & $\mathrm{pCvKB3}$ & $\mathrm{pCvKB} 4$ & PCvKB5 & pCvKB6 & pCvKB9 & $\mathrm{pCvKB} 10$ \\
\hline \multirow[t]{2}{*}{ Iridaceae } & Romulea & bulbocodium & - & 0 & 1 & 1 & 1 & - & - \\
\hline & Iris & magnifica & 0 & 0 & 0 & 1 & 1 & - & 0 \\
\hline \multirow[t]{3}{*}{ Liliaceae } & Erythronium & cv. 'Pagoda' & - & 0 & 0 & 0 & - & - & - \\
\hline & Tulipa & turkestanica & 0 & 0 & 0 & 0 & 0 & - & 0 \\
\hline & Fritillaria & imperalis & 0 & 0 & 0 & 0 & 0 & - & 0 \\
\hline Amaryllidaceae & Narcissus & pseudo-narcissus & 0 & 0 & 0 & 0 & 0 & - & 0 \\
\hline
\end{tabular}

Note: -, Not investigated; 0 , hybridization signal not detectable or extremely weak; 1 , signal weaker than $C$. vernus; 2 , signal strength as strong as $C$. vernus or stronger.

it from species in the other subgenus Crocus. In contrast, six of the seven repetitive sequences are not detected in C. korolkowii, placed in the subgenus Crocus. Furthermore, the subdivision of the subgenus Crocus into two sections (see Table 3) is not reflected in the distribution of the sequences; no sequence was largely absent from section nudiscapus and present in section crocus.

Is the sequential model of sequence evolution wrong? Or is the valuable taxonomic classification of Crocus unrelated to evolution in the genus? If evolution has been explosive, with rapid radiation of new species, then the slow processes of repetitive sequence divergence and homogenization could not be expected to be informative. In such cases, taxonomy may be based on informative but fundamentally autapomorphic characters based on a small number of genetic differences. More recent inter-taxon hybridization, with continuing homogenization of repetitive sequences, would make it extremely difficult to reconstruct the phylogeny, even using combinations of molecular, genetic, chromosomal, and morphological analyses. We think that such a pattern for the evolution of the genus Crocus is more likely than the occurrence of many parallel and repeated events in sequence evolution.

\section{Acknowledgements}

We thank Niels Jacobsen, Marian Ørgaard, and Trude Schwarzacher for careful reading of the manuscript. Furthermore, we thank Niels Jacobsen and Marian Ørgaard for their help in providing plants, and for valuable discussions. Gill Harrison has been of great help in the laboratory. Kell Kristiansen has been part of the team collecting the plants for this investigation. This project was supported by a grant from The Royal Veterinary and Agricultural University of Copenhagen. Work on biodiversity and retroelements was supported by EC grant BIO4CT960508. 
Fig. 5. Sau3AI digests of genomic DNA from Crocus and allies after agarose gel electrophoresis and ethidium bromide staining showing smears of cut DNA. No major bands are visible in the digests. Southern transfer of the gel probed with the repetitive DNA clone pCvKB4 shows presence of the sequence in all Crocus species, except C. korolkowii, and Romulea. Multiple restriction fragments are shared between most lanes showing hybridization, although the signal strength varies. Lanes: a, C. vernus; b, C. kosaninii; c,

C. imperati; d, C. medius; e, C. kotchyanus; f, C. dalmaticus; g, C. chrysanthus; h, C. korolkowii; i, C. flavus; j, C. speciosus; k, C. laevigatus; 1, C. banaticus; m, Romulea bulbocodium; n, Iris magnifica; o, Erythronium 'Pagoda'; p, Tulipa turkestanica; q, Fritillaria imperalis; r, Narcissus pseudonarcissus; s, 100-bp ladder with 100 bp just below the illustration, double band at 800 bp.

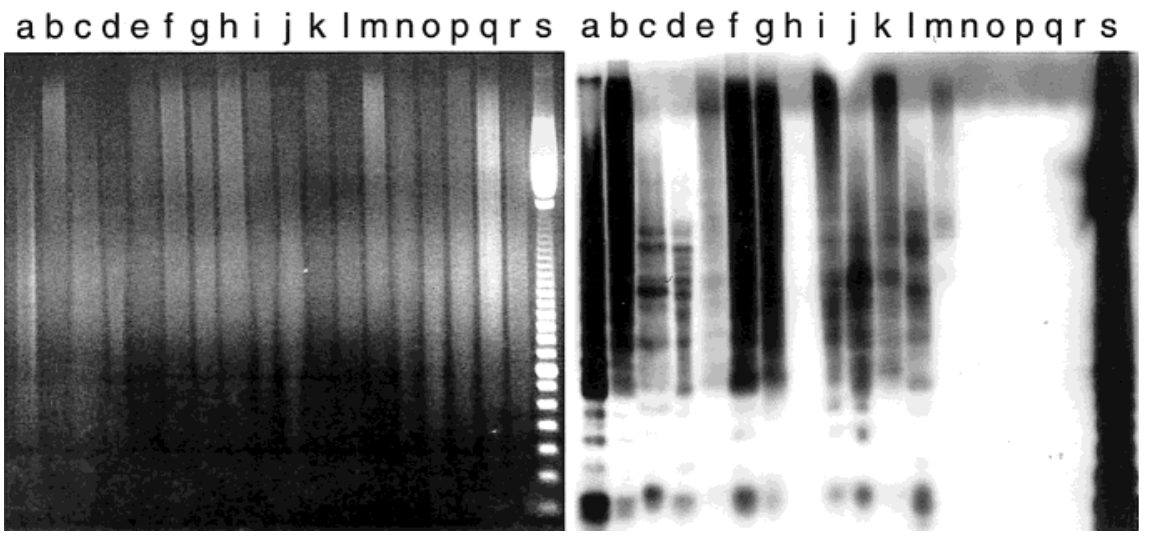

Fig. 6. Sau3AI digests of genomic DNA from Crocus and allies after agarose gel electrophoresis and ethidium bromide staining showing smears of cut DNA. Southern transfer of the gel probed with the repetitive DNA clone pCvKB5 showing presence of the sequence in 6 of the 12 Crocus species tested. More than 15 restriction fragments are present in C. vernus, but other species have mostly different and a much smaller number of hybridizing fragments. Lanes: a, C. vernus; b, C. kosaninii; c, C. imperati; d, C. medius; e, C. kotchyanus; f, C. dalmaticus; g, C. chrysanthus; h, 250-bp ladder from lowest band, double band at $1 \mathrm{~kb}$; i, C. korolkowii; j, C. antalyensis; $\mathrm{k}$, C. speciosus; 1 , C. laevigatus; $\mathrm{m}$, C. banaticus. Second gel (longer autoradiograph exposure than lanes a to m; lane $\mathrm{n}$ loaded with less DNA than o to s; cf. lanes a and n): n, C. vernus; o, Romulea bulbocodium; p, Iris magnifica; q, Tulipa turkestanica; r, Fritillaria imperalis; s, Narcissus pseudonarcissus; t, lambda-EcoRI-HindIII double digest.

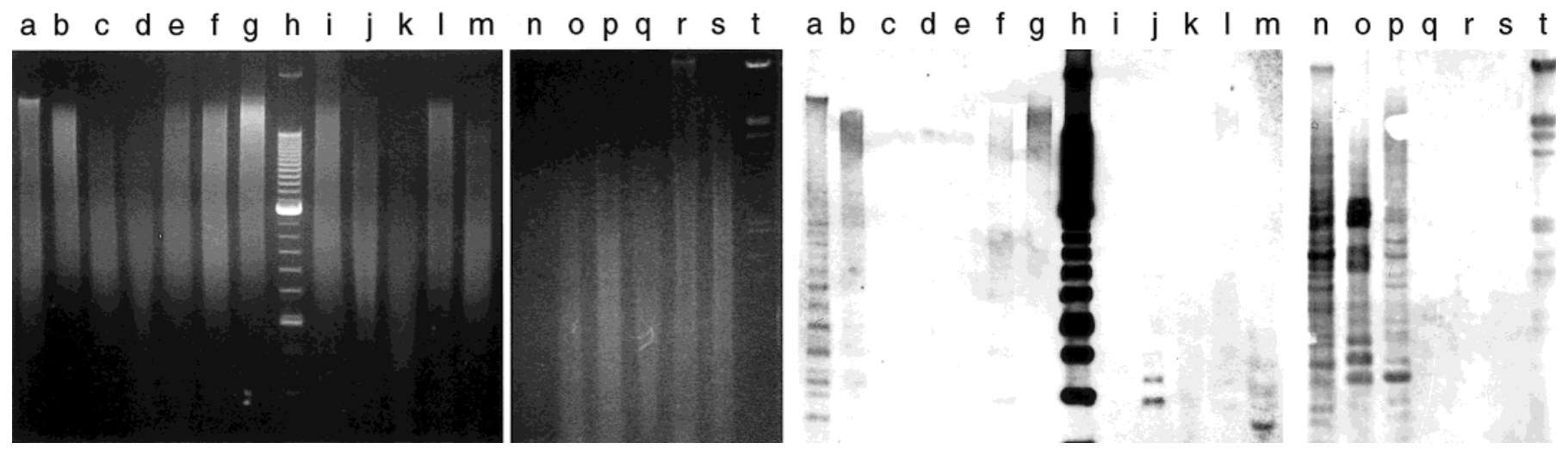

\section{References}

Avramova, Z., SanMiguel, P., Georgieva, E., and Bennetzen, J.L. 1995. Matrix attachment regions and transcribed sequences within a long chromosomal continuum containing maize Adh1. Plant Cell, 7: 1667-1680.

Brandes, A., Heslop-Harrison, J.S., Kamm, A., Kubis, S., Doudrick, R.L., and Schmidt,T. 1997. Comparative analysis of the chromosomal and genomic organization of Ty1-copia-like retrotransposons in pteridophytes, gymnosperms and angiosperms. Plant Mol. Biol. 33: $11-21$.

Busch, W., and Herrmann, R.G. 1997. Repeated DNA sequences isolated by microdissection. II. Comparative analysis in Hordeum vulgare and Triticum aestivum. Theor. Appl. Genet. 93: 164-171.
Charlesworth, B., Sniegowski, P., and Stephan, W. 1994. The evolutionary dynamics of repetitive DNA in eukaryotes. Nature, 371: 215-220.

de Bustos, A., Cuadrado, A., Soler, C., and Jouve, N. 1996. Physical mapping of repetitive DNA sequences and 5S and 18S-26S rDNA in five wild species of the genus Hordeum. Chromosome Res. 4: 491-499.

Flavell, R.B. 1986. Repetitive DNA and chromosome evolution in plants. Philos. Trans. R. Soc. Lond. B Biol. Sci. No. 312: 227 242.

Flavell, A.J., Dunbar, E., Anderson, R., Pearce, S.R., Hartley, R., and Kumar, A. 1992. Ty1-copia group retrotransposons are ubiquitous and heterogeneous in higher plants. Nucleic Acids Res. 20: 3639-3644. 
Flavell, A.J., Pearce, S.R., Heslop-Harrison, J.S., and Kumar, A. 1997. The evolution of Ty1-copia group retrotransposons in eukaryote genomes. Genetica, 100: 185-195.

Frello, S., and Heslop-Harrison, J.S. 2000. Chromosomal variation in Crocus vernus Hill (Iridaceae) investigated by in situ hybridization of rDNA and a tandemly repeated sequence. Ann. Bot. (London), 86: 317-322.

Itoh, K., Iwabuchi, M., and Shimamoto, K. 1990. In situ hybridization with species-specific DNA probes gives evidence for asymmetric nature of Brassica hybrids obtained by X-ray fusion. Theor. Appl. Genet. 81: 356-362.

Kamm, A., Doudrick, R.L., Heslop-Harrison, J.S., and Scmidt, T. 1996. The genomic and physical organization of Ty1-copia-like sequences as a component of large genomes in Pinus elliotti var. elliotti and other gymnosperms. Proc. Natl. Acad. Sci. U.S.A. 93: $2708-2713$.

Katsiotis, A., Scmidt, T., and Heslop-Harrison, J.S. 1996. Chromosomal and genomic organization of Tyl-copia-like retrotransposon sequences in the genus Avena. Genome, 39: 410-417.

Kubis, S., Schmidt, T., and Heslop-Harrison, J.S. 1997. A family of differentially amplified repetitive sequences in the genus Beta reveals genetic variation in Beta vulgaris subspecies and cultivars. J. Mol. Evol. 44: 310-320.

Kubis, S., Schmidt, T., and Heslop-Harrison, J.S. 1998. Repetitive DNA elements as a major component of plant genomes. Ann. Bot. (London), 82(A): 45-55.

Kumar, A., Pearce, S.R., McLean, K., Harrison, G., Heslop-
Harrison, J.S., Waugh, R., and Flavell, A.J. 1997. The Ty1copia group of retrotransposons in plants: Genomic organisation, evolution and use as molecular markers. Genetica, 100: 205-217.

Mathew, B. 1982. The Crocus, A revision of the genus Crocus (Iridaceae). B.T. Batsford Ltd., London.

Ørgaard, M., Jacobsen, N., and Heslop-Harrison, J.S. 1995. The hybrid origin of two cultivars of Crocus (Iridaceae) analysed by molecular cytogenetics including genomic Southern and in situ hybridization. Ann. Bot. (London), 76: 253-262.

Pearce, S.R., Pich, U., Harrison, G., Flavell, A.J., Heslop-Harrison, J.S., Schubert, I., and Kumar, A. 1996. The Ty1-copia group retrotransposons of Allium cepa are distributed throughout the chromosomes but are enriched in the terminal heterochromatin. Chromosome Res. 4: 357-364.

Sambrook, J., Fritsch, E.F., and Maniatis, T. 1989. Molecular Cloning: A Laboratory Manual. 2nd ed. Cold Spring Harbor Laboratory Press, Cold Spring Harbor, N.Y.

Schwarzacher, T. and Heslop-Harrison, J.S. 2000. Practical in situ hybridization. Bios, Oxford.

Svitashev, S., Bryngelsson, T., Vershinin, A., Pedersen, C., Sall, T., and von Bothmer, R. 1994. Phylogenetic analysis of the genus Hordeum using repetitive DNA sequences. Theor. Appl. Genet. 89: $801-810$.

Vershinin, A., Schwarzacher, T., and Heslop-Harrison, J.S. 1995. The large scale genomic organization of repetitive DNA families at the telomeres of rye chromosomes. Plant Cell, 7: 1823-1833. 